Int. J. Dev. Biol. 48: 559-562 (2004)

\title{
Tumor invasion and metastasis: getting more basic to come closer to the patient An interview with Lance A. Liotta
}

\author{
VINCENT CASTRONOVO* \\ Metastasis Research Laboratory, University of Liège, Sart Tilman, Liège, \\ Belgium
}

Lance Liotta, M.D., Ph.D. is one of the pioneers who opened, in the 1970s, a major new alley of investigation in the field of cancer research: the study of the mechanisms which sustain tumor invasion and metastasis. Using his outstanding creative mind and his expertise in biomedical engineering, he has proposed over the years powerful, innovative concepts which have inspired the whole scientific community in the field of cancer. He is the author of the three step model for tumor invasion (degradation, adhesion and migration of cancer cells) which has guided and enlightened tens if not hundreds of researchers, leading to incredible progress in our understanding of the mechanisms used by malignant cells to progress during their walk from the primary tumor to the deadly secondary colonies. With his colleagues, he invented Laser Capture Microdissection (LCM), an ingenious apparatus used today in more than 500 laboratories worldwide, which has enabled researchers to explore for the first time, the real time events occurring during cancer progression. One of his last achievements, among many, is a novel Drosophila model which can be genetically manipulated to study the key genetic events underlying tumor invasion and metastases.

Cancer invasion and metastasis are the major causes of the failure of cancer treatment. Targeting these processes in an attempt to find a cure for cancer appears nowadays a sound and logical

approach. This was not the case back in the 1970s, a time when the major efforts in cancer research aimed to stop the uncontrolled proliferation of malignant cells. Lance Liotta, M.D., PhD is a major pioneer who initiated and opened new alleys of research by studying the molecular mechanisms which lead a cancer cell to leave the primary tumor, successfully invade and cross the barriers encountered during its progression, penetrate the blood stream to be transported to a distant location where it can seed and develop into a secondary colony, a metastases. Dr. Liotta is chief of the Laboratory of Pathology and chief of the section of Tumor Invasion and Metastases in the Center for Cancer Research, at the National Cancer Institute $(\mathrm{NCl})$ of the national Institutes of Health $(\mathrm{NIH})$. He is the former deputy director for Intramural Research, $\mathrm{NIH}$. He received his undergraduate degree at Hiram College in 1969 and went on to complete an M.D./PhD. program at Case Western Reserve University in 1976. Dr. Liotta's Ph.D. was in biomedical engineering with cancer metastasis as his Ph.D. topic. He served his residency training in anatomic pathology at the $\mathrm{NIH}$ in the Laboratory of Pathology and became chief of the same laboratory in 1982. Dr. Liotta is chair of the NIH Radiation Safety Committee. He is the author or co-author of 424 peer-reviewed publications to date.

I had the great chance and privilege to work as a post-doctoral fellow in the laboratory of Dr Lance Liotta, at the Laboratory of

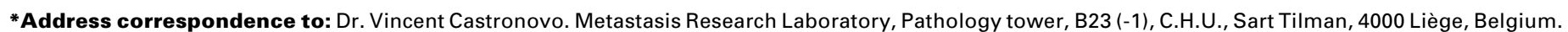
Fax: +32-4366-2975. e-mail: vcastronovo@ulg.ac.be
} 


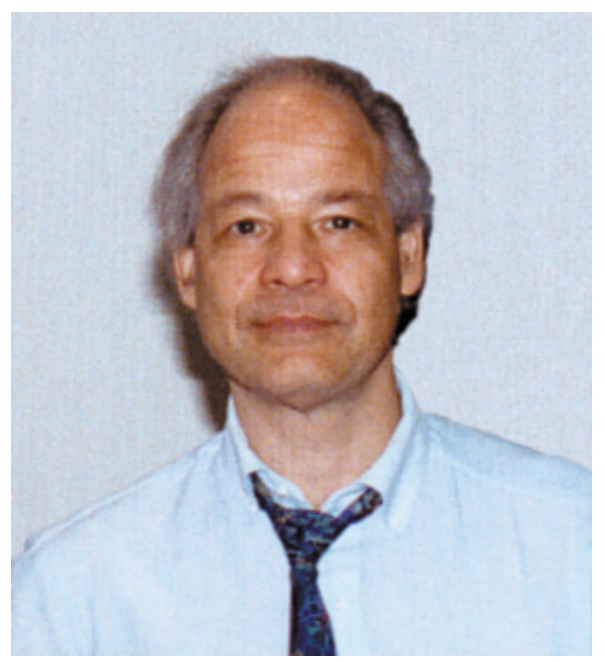

Pathology at the National Cancer Institute in Bethesda (MD, USA) from 1987 to 1992 . My project was to study the $67 \mathrm{kDa}$ laminin receptor, initially identified by Dr Liotta's group and involved during cancer progression, under the wonderful supervision of Dr Mark Sobel. During this period, one of the best so far in my professional carrier, I had the honor to work with Dr Lance Liotta. Enthusiasm, creativity, brightness, humbleness, friendship are among the several qualities that best define Lance Liotta. He really has a natural talent to communicate his research enthusiasm to the youngest and has launched the carrier of many successful scientists. He has the unique capability to merge his scientific knowledge with the latest state of the art technologies to create new concepts, new approaches that are always incredibly powerful to help his leading objective: contributing to find new effective approaches to help cancer patients.

Lance Liotta and colleagues invented Laser Capture Microdissection (LCM), which is commercialized by Arcturus and used today in more than 500 laboratories worldwide. This potent technology has conducted scientists to develop cDNA libraries of normal tissues, premalignant precursor lesions, invasive cancer, adjacent stroma and metastasis, all from the same patient. In collaboration with Dr. Emanuel Petricoin of the Food and Drug Administration (FDA), he has initiated the first joint initiative between the FDA and the $\mathrm{NCl}$ to develop new technologies for the discovery of proteins and the profiling of signal pathways in human tissue. Their project is to use, for the first time, "artificial intelligence" type learning algorithms to discover disease-associated proteomic patterns. They have proposed that LCM combined with protein microarrays constitutes a new paradigm for studying the mechanism of action of candidate pharmaceuticals. For clinical trials, the technology is being applied to patient tissue biopsies conducted before, during and after experimental therapy.

Always seeking for unexplored alleys of research, Lance Liotta's group has developed a novel Drosophila model which can be genetically manipulated to switch on the malignant invasive phenotype in cell types that are the precursors of solid tumors. A large number of mutants can be rapidly screened to evaluate phenotypic alterations in the in vivo locomotion and invasion of genetically altered cells. They have shown that loss of function of specific Drosophila tumor suppressors leads to metastatic tumors. Three such mutants are lethal giant larvae (lgl), discs large (dlg)and brain tumor (brat). These Drosophila tumor suppressor mutants have similar phenotypes and the proteins they encode may have related functions. The Drosophila invasion model starts with flies that are lacking one copy of a tumor suppressor gene such as $\mid g /$. Larvae lacking both copies of the $\mathrm{g} / \mathrm{g}$ gene can be generated from heterozygous parents. Loss of function of both $/ \mathrm{g} / \mathrm{genes}$ produces neoplastic growths. Brain fragments, or epithelial imaginal discs, when transplanted into adult fly hosts, yield tumor cells which are highly motile, invasive and metastatic. After screening thousands of mutations that suppress or enhance the metastasis of lethal giant larvae brain tissue, they have identified four genes that are functionally required for different stages of the Drosophilaphenotype of invasion and metastasis. The genes provide new insights into the mechanism of cancer invasion in humans.

I really appreciated the chance to interview Lance Liotta. The interview for obvious practical reasons was conducted via electronic mail.

\section{Lance, could you tell me some information regarding your life as a kid, your parents, school and hobbies?}

I was born in Cleveland, Ohio, USA. I have one brother and one sister. My father was a high school science teacher in charge of the local public school science department. Science and English composition were my best subjects both at elementary and high school. My hobbies were /are making things and inventing things. In high school in the 60 s, I made a hovercraft powered by a lawn mower engine, a robot arm which could be taught to do tasks and a roving robot that could survive on its own and plug itself in to the charger. My sport was wrestling. I was undefeated as a senior in high school. I am married to my college sweetheart and we have two children and now two grandchildren.

\section{When and why did you decide to go to medical school?}

I was interested in cells as micro machines and I was interested in biology and engineering. To cover all these areas I enrolled in a $\mathrm{PhD}$ program in biomedical engineering concomitant with medical school: MD PhD program at Case Western Reserve in Cleveland, Ohio. When I was choosing my PhD subject, no one knew anything about metastasis or invasion of cancer. Work at that time was focused on cancer growth rates. I chose the topic because it was uncharted territory and I could use both an engineering and biology

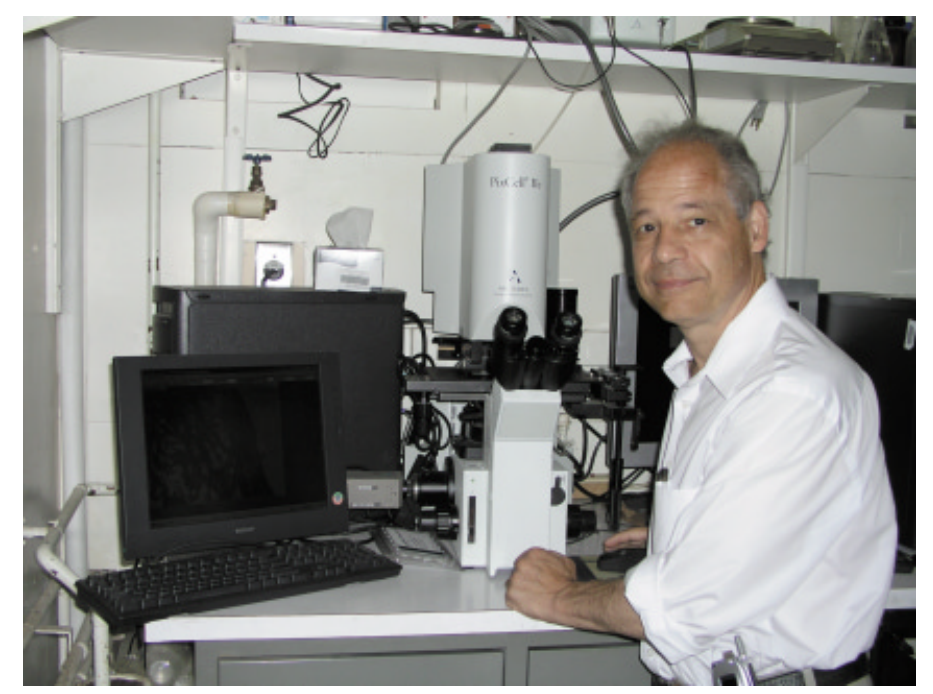


approach. I had two PhD mentors: Dr. Kleinerman a pathologist and Dr. Saidel a biomathematician.

You are one of the pioneers who initiated a major shift in cancer research from the study of the mechanisms of cancer cell proliferation to the examination of the molecular mechanisms of tumor invasion and metastasis. What inspired you to orient your research toward this unexplored direction?

I only want to work on new territory. In 1969-70 I read a European book reporting some of the first EM [ed. electron microscopic] pictures of blood vessels and tumor cells invading the extracellular matrix. This made me want to understand the connection between these elements. Consequently I planned my PhD research to develop an animal model of cancer dissemination in which I could measure the entry of tumor cells in the circulation as the tumor grew and then correlate the cell shedding with the development of new blood vessels in the tumor. I read an article by Kefalides in Philadelphia in the 1970s who proposed

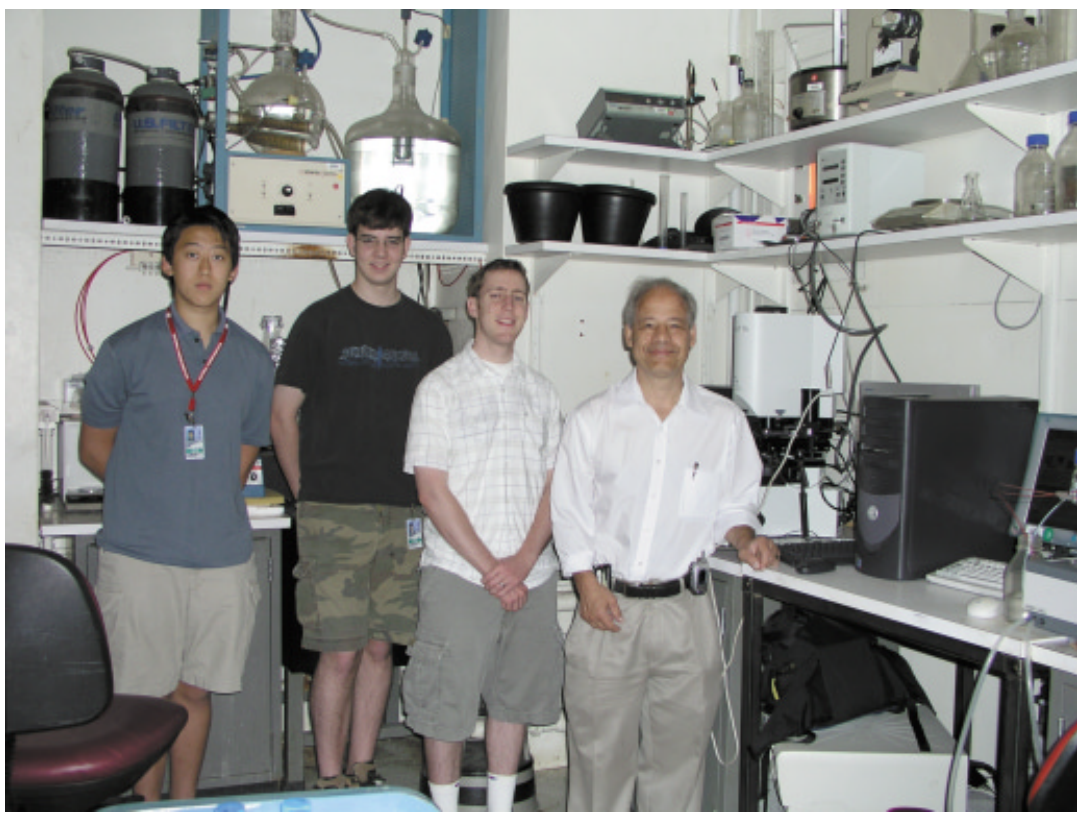
that basement membrane collagen was different than the one known collagen type. This made me think that the extracellular matrix was a rich avenue for exploration. Using his method I extracted basement membranes from hundreds of mouse lungs and cultured tumor cells on this substratum. I observed the tumor cells migrate within and through this matrix and this led to the hypothesis about the three steps of invasion.

Your three step model for tumor invasion (degradation, adhesion and migration of cancer cells) guided tens if not hundreds of researchers who have worked on your theory. How did you come up with this model? What are the major discoveries that were generated by your model?

In general this model led to a large body of scientists studying the role of tumor cell interactions with the extracellular matrix, characterizing the extracellular matrix molecules and discovering the enzymes, enzyme inhibitors and adhesion molecules. The role of the ECM [ed. extracellular matrix] and the tumor microenvironment continues to be a fertile area.

What were the reactions of the scientific community toward this new concept? How do this model stand circa 25 years after you have proposed it?

No one in the cancer field was studying the extracellular matrix at the time. At the Gordon conference, no one believed that there was more than one type of collagenase, collagenase inhibitor and no one accepted matrix receptors as triggers for cell attachment, growth and motility. Now we have dozens of collagens, MMPs [ed. matrix metalloproteases], TIMPs [ed. tissue inhibitor of matrix metalloproteases], integrins, etc.

Among the several major discoveries of yours is the identification and characterization of matrix metalloproteases as key enzymes for the degradation of extracellular matrix, a process which is determinant for tumor progression. Since your initial publications, the field of matrix proteases has literally exploded. Huge clinical hope has been put on the concept of

treatments based on the inhibition of these enzymes. For many years, your personal interest was focused on these enzymes? Why? Where do we stand today with the clinical applications of this concept?

Inhibitors of metalloproteinases have been tested in patients who already have advanced disease. Invasion and metastasis already exists. Consequently it is too late in the disease to see if this treatment prevents the transient processes of invasion. Now we know from transgenic models that MMPs are important for angiogenesis, invasion and local growth. The understanding of the biological role of these enzymes has exploded in all directions.

Several years ago, you started a completely new, innovative field of research: the exploration of gene and protein expression in specific cells isolated from tissues. Your claim was that to know which genes and proteins were expressed in a specific type of cancer cell in the process of doing a specific task, you need to study exactly these cells and not adjacent cells which might be engaged in a different process. This thesis of yours led you to invent an incredible instrument which enabled the collection of single cells from tissue: the Laser Capture Microdissector. Can you tell us how you matured this new concept and what inspired you to create such a fantastic new instrument? Was it easy? What were the pitfalls?

As a pathologist I wanted to study what happens in the microenvironment of real human cancer during the transition from in situto invasive cancer. There was no way to study this in animal models or in vitro. While sitting in a boring meeting I came up with the idea of laser capture and I tested the concept in my basement using a tissue section on a slide, some Japanese silk screen thermoplastic film and an infrared flash lamp which I focused through a metal aperture. The method worked perfectly so I filed an NIH patent disclosure and set up a series of testing experiments for using the method for DNA ( $\mathrm{LOH}$ ) and proteins. I wrote up a proposal including the use of virtual robotic dissection (LCM using a histologic image 
on a screen and a computer mouse; the computer then directs the laser to microdissect the cells chosen on the screen). The robotic version, built by Arcturus, is now in our lab! Dr. Emmert Buck, Dr. Robert Bonner and I published this method in Sciencein 1998 and in one year the commercial instrument was on sale licensed by Arcturus.

What is the discovery that you are the more proud of?

I am most proud of the latest invention/ project I am working on. Application of LCM tissue and blood to our new technologies for proteomics has been unbelievable.

Lance Liotta is among the few great scientists involved in cancer research. The word "pioneer" is what defines him best. His brilliant and creative mind produces new paradigms which feed research communities and open up original and very promising alleys of research. We only can hope that he will continue for many more years to put his energy and enthusiasm to the service of cancer research. No doubt he will.

\section{References}

CASTRONOVO, V., TARABOLETTI,G., LIOTTA, L.A. and SOBEL, M.E. (1989). Modulation of laminin receptor expression by estrogen and progestins in human breast cancer cell lines. J Nat/ Cancer Inst. 81(10):781-8.

EMMERT-BUCK, M.R., BONNER, R.F., SMITH,P.D., CHUAQUI, R.F., ZHUANG, Z., GOLDSTEIN, S.R., WEISS, R.A and LIOTTA, L.A. (1996). Laser capture microdissection. Science. 274:998-1001.

LIOTTA, L.A. (1986). Tumor invasion and metastases-role of the extracellular matrix: Rhoads Memorial Award lecture. Cancer Res. 46(1):1-7.
LIOTTA, L.A. and KOHN, E.C. (2003). Cancer's deadly signature. Nat. Genet.33:10-

LIOTTA, L.A. and KOHN, E.C. (2001). The microenvironment of the tumour-host interface. Nature. 411:375-9.

LIOTTA, L.A and STETLER-STEVENSON, W.G. (1991). Tumor invasion and metastasis: an imbalance of positive and negative regulation. CancerRes. 51:5054s5059.

PETRICOIN, E.F., ARDEKANI, A.M., HITT, B.A., LEVINE, P.J., FUSARO, V.A., STEINBERG, S.M., MILLS, G.B., SIMONE, C., FISHMAN, D.A., KOHN, E.C. and LIOTTA L.A. (2002). Use of proteomic patterns in serum to identify ovarian cancer. Lancet. 359:572-7.

ROSENBLATT, K.P., BRYANT-GREENWOOD, P., KILLIAN, J.K., MEHTA, A., GEHO, D., ESPINA, V., PETRICOIN, E.F. and LIOTTA, L.A. (2004). Serum proteomics in cancer diagnosis and management. Annu. Rev. Med. 55:97-112.

PETRICOIN, E.F., ORNSTEIN, D.K., PAWELETZ, C.P., ARDEKANI, A., HACKETT, P.S., HITT,B.A., VELASSCO, A., TRUCCO, C., WIEGAND, L., WOOD, K., SIMONE, C.B., LEVINE, P.J., LINEHAN, W.M., EMMERT-BUCK, M.R., STEINBERG, S.M., KOHN, E.C. and LIOTTA, L.A. (2002). Serum proteomic patterns for detection of prostate cancer. J. Natt. Cancer Inst. 94:1576-8.

PETRICOIN, E.F., ZOON, K.C., KOHN, E.C., BARRETT, J.C. and LIOTTA, L.A. (2002).Clinical proteomics: translating benchside promise into bedside reality. Nat. Rev. Drug. Discov. 1:683-95.

SIMONE, N.L., BONNER,R.F., GILLESPIE, J.W., EMMERT-BUCK, M.R. and LIOTTA LA. (1998). Laser-capture microdissection: opening the microscopic frontier to molecular analysis. Trends Genet.14:272-6.

SIMONE, N.L., PAWELETZ, C.P., CHARBONEAU,L., PETRICOIN, E.F. and LIOTTA L.A. (2000). Laser capture microdissection: beyond functional genomics to proteomics. Mol Diagn. 5:301-7.

WOODHOUSE, E.C., FISHER, A., BANDLE, R.W., BRYANT-GREENWOOD, B., CHARBONEAU, L., PETRICOIN, E.F. and LIOTTA, L.A. (2003). Drosophila screening model for metastasis: Semaphorin $5 \mathrm{c}$ is required for $\mathrm{I}(2) \mathrm{gl}$ cancer phenotype. Proc. Natl. Acad. Sci. 100:11463-8.

WOODHOUSE, E.C. and LIOTTA, L.A. (2004). Drosophila invasive tumors: a model for understanding metastasis. Cell. Cycle. 3:38-40. 